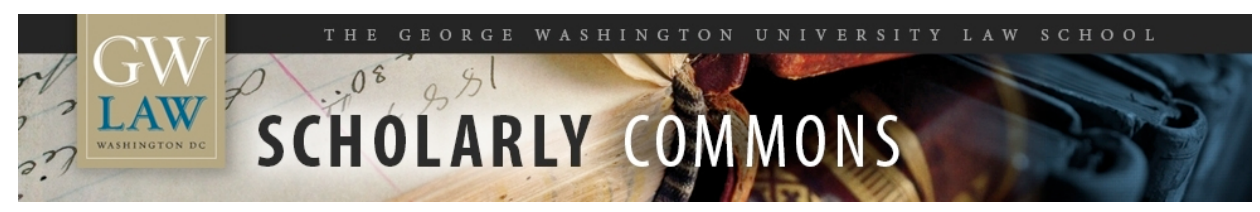

GW Law Faculty Publications \& Other Works

Faculty Scholarship

2018

\title{
Global Legal Pluralism as a Normative Project
}

Paul Schiff Berman

George Washington University Law School, pberman@law.gwu.edu

Follow this and additional works at: https://scholarship.law.gwu.edu/faculty_publications

Part of the Law Commons

\section{Recommended Citation}

Berman, Paul Schiff, Global Legal Pluralism as a Normative Project (2018). 8 UC Irvine L. Rev. 149 (2018).; GWU Law School Public Law Research Paper No. 2018-76; GWU Legal Studies Research Paper No. 2018-76. Available at SSRN: https://ssrn.com/abstract=3288690

This Article is brought to you for free and open access by the Faculty Scholarship at Scholarly Commons. It has been accepted for inclusion in GW Law Faculty Publications \& Other Works by an authorized administrator of Scholarly Commons. For more information, please contact spagel@law.gwu.edu. 


\title{
Global Legal Pluralism as a Normative Project
}

\author{
Paul Schiff Berman*
}

Introduction

I. Global Legal Pluralism As a Descriptive Project ..................................................154

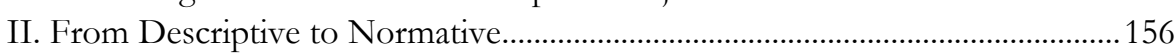

III. Legal Pluralism and the Idea of Communication Across Difference ..............158

IV. Building a Normative Global Legal Pluralism...................................................... 161

V. Six Mechanisms for Managing Legal Pluralism .................................................. 165

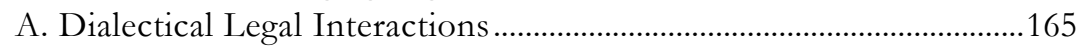

B. Margins of Appreciation ……................................................................. 170

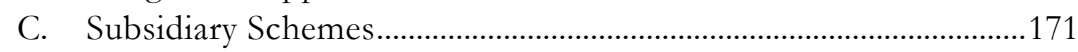

D. Hybrid Participation Arrangements ........................................................173

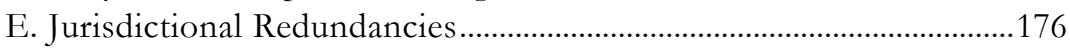

F. Migration, Assimilation, and Integration ............................................177

VI. Can Global Legal Pluralism Be Normative and Still Be Pluralist? ...................178

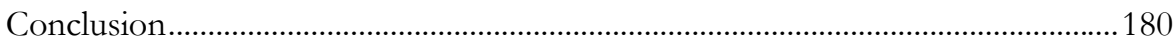

\section{INTRODUCTION}

We are living in dark, dark times. In Europe and the United States, the institutions of interlocking governance and democratic coexistence that have been carefully nurtured since 1945 are under attack. Nationalism, tribalism, xenophobia, and racism are fueling right-wing populist revolts against this legal order despite the fact that the period since 1945 has seen rises in health, longevity, prosperity, and peace that are perhaps unparalleled in human history.

Most fundamentally, we are in grave danger of losing sight of the core values that were forged out of the ashes of World War II and its unimaginable horrors.

\footnotetext{
* Walter S. Cox Professor of Law, The George Washington University Law School. This Article was prepared as part of a Symposium on Legal Pluralism held at the University of California, Irvine School of Law. Some material derived from PAul SChiff Berman, Global LEgAl PluRAlism: A JURISPRUDENCE OF LAW BEYOND BORDERS (2012).
} 
Those values include the very idea of democratic dialogue, international cooperation, protection of human rights, respect for diversity, the moral worth of each individual, the idea of limits on what nation-states can do to pursue their selfinterest, and so on. Witnessing the first two decades of the twenty-first century, it seems that those values, as well as the institutions needed to help protect them, may be far more fragile than perhaps most of us realized. And so they need to be articulated and defended, again and again. By everyone and anyone.

Paradoxically and tragically, this move towards greater insularity and tribalism comes at a time when many of the problems facing the world increasingly require coordinated solutions and more interaction among legal and political systems, not less. Such problems include: issues of how we will effectively maintain life on this planet (climate change, biodiversity, ecosystem losses, and water deficits); issues of how human beings will sustain themselves on it (poverty, conflict prevention, and global infectious diseases); and issues of how we will develop global cooperative rules for living together given that much human activity crosses territorial borders (nuclear proliferation, toxic waste disposal, data protection, trade rules, finance and tax regimes, and so on). These sorts of problems cannot plausibly be addressed solely within one legal system.

Yet, despite these obvious needs, we see resistance to global governance or universalistic solutions. This resistance may stem from concerns about the democratic accountability of such solutions or a belief that global solutions are intrinsically hegemonic. Indeed, an emphasis on the global might seem to give insufficient attention to the local affiliations and emotional attachments people at least sometimes hold onto most assiduously. Or universalism might be seen to trample on the ideal of diversity altogether.

Thus, the legal challenge of our time is how to build mechanisms for engagement among legal, political, or cultural systems that recognize at least a limited set of shared values and promote mutual respect, dialogue, and cooperation, without requiring all systems to be homogenized into one universalistic legal order. We must create what David Held has called "the ethical and political space which sets out the terms of reference for the recognition of people's equal moral worth, their active agency and what is required for their autonomy and development." 1 But at the same time, we must recognize that the meaning of principles such as equal concern and regard, human dignity, and so on cannot be specified once and for all, separate from the diversity of traditions, beliefs, histories, and cultures that make up human societies. In the end, what we need are institutions, procedures, and practices that allow for dialogue and cooperation under conditions of diversity.

I believe legal pluralists should take up this challenge and help develop principles that might underlie the kinds of institutions, procedures, and practices that might be needed to perform this delicate balancing act. Indeed, scholars of legal pluralism are well positioned to understand the many ways in which legal systems

1. DAVID HeLD, CoSmopolitanism: IDEALS AND REALITIES 49 (2010). 
and governmental institutions respond to the realities of diversity and the existence of multiple norm-generating communities operating simultaneously in the same social space.

Legal pluralists have long recognized that societies consist of such multiple overlapping normative communities. These communities are sometimes state-based but sometimes not, and they are sometimes formal, official, and governmental, but again sometimes they are not. Scholars studying interactions among these multiple communities have often used the term "legal pluralism" to describe the inevitable intermingling of these normative systems. ${ }^{2}$

In recent decades, a new application of pluralist insights has emerged in the international and transnational realm. This new legal pluralism research was born in the decades following the collapse of the bipolar Cold War order in $1989 .{ }^{3}$ During this period, it became clear that a single-minded focus on state-to-state relations or universal overarching norms was inadequate to describe the reality of the emerging global legal system, with its web of jurisdictional assertions by state, international, and non-state normative communities. As one commentator put it:

The nation-state and the interstate system are the central political forms of the capitalist world system, and they will probably remain so for the foreseeable future. What has happened, however, is that they have become an inherently contested terrain, and this is the central new fact on which the analysis must focus: the state and the interstate system as complex social fields in which state and non-state, local and global social relations interact, merge and conflict in dynamic and even volatile combinations. ${ }^{4}$

Legal pluralism provided a useful alternative framework because pluralism had always sought to identify hybrid legal spaces, where multiple normative systems occupied the same social field. And though pluralists had often focused on clashes within one geographical area, where formal bureaucracies encountered indigenous ethnic, tribal, institutional, or religious norms, the pluralist lens proved highly adaptive to analysis of the hybrid legal spaces created by a different set of overlapping jurisdictional assertions (state v. state, state v. international body, state v. non-state entity) in the global arena. ${ }^{5}$

An emphasis on legal pluralism also freed scholars from endless intractable debates about whether international law is truly law given that coercive enforcement power in the international and transnational arena is often indirect or nonexistent.

2. For a brief history of some of the key legal pluralism literature, see generally Paul Schiff Berman, The New Legal Pluralism, 5 ANN. REV. L. \& SOC. SCI. 225 (2009).

3. For a discussion of this literature, see generally Paul Schiff Berman, The Evolution of Global Legal Pluralism, in Authority in Transnational Legal TheOrY: Theorising Across DisCIPLINES (Roger Cotterrell \& Maksymilian Del Mar eds., 2016).

4. Boaventura de Sousa Santos, Toward a New Legal Common Sense: Law, GLOBALIZATION, AND EMANCIPATION 94 (2d ed. 2002).

5. For a discussion of this trajectory in legal pluralism scholarship, see generally Paul Schiff Berman, From Legal Pluralism to Global Legal Pluralism, in LAW, SOCIETY AND COMMUNITY:

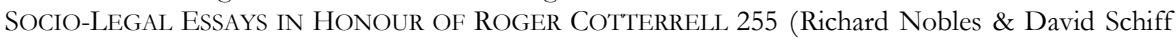
eds., 2014). 
Such debates had created stagnation in the international law and international relations literature as both international law triumphalists and nation-state sovereigntists talked past each other with either an overly formalist faith in international law's inherent authority, on the one hand, or an overly formalist rejection of any law beyond the nation-state, on the other.

Global legal pluralism applies the insights of socio-legal scholarship and turns the gaze away from abstract questions of legitimacy and towards empirical questions of efficacy. Thus, pluralists de-emphasize the supposed distinctions between a norm, a custom, a law, a moral command, a sociological consensus, a psychological imperative, or the like. Instead, a pluralist approach focuses on both enacted law and what has sometimes been called "implicit" or "interactional" law, the purposive practices that groups of people enter into and that impact their practical sense of binding obligation. ${ }^{6}$ In addition, pluralists recognize that both enacted and interactional legal norms tend to seep into consciousness over time, such that the mere existence of these commands, whether enforced or not, may sometimes alter the power dynamics or options placed on the table in policy discussions. Thus, legal authority is always relative and always contested, and legal pluralists argue that our models for describing law should reflect that pluralism.

As should be clear from this brief summary, legal pluralism has been primarily a descriptive enterprise. Anthropologists, historians, and other social scientists have generally seen legal pluralism as simply a reality, neither good nor bad, neither desirable nor undesirable. Instead, they have defined their task principally as an exercise in thick description: cataloging the inevitable hybridity that arises when multiple legal or quasi-legal systems occupy the same social space, as well as the resulting strategic interactions that occur among those navigating the various regimes.

This is not to say, of course, that legal pluralism as a scholarly project was (or ever could be) devoid of implicit values and normative biases. Indeed, one might say that two strong normative undercurrents have always animated legal pluralism. First, legal pluralism was an attack on legal centralism, the idea that law was the sole province of the state and its formal institutions. ${ }^{7}$ Pluralists sought to undermine the assumption of state power, discovering agency and subversive opportunities among those presumed to be marginalized. As such, legal pluralism was a way of critiquing the power of the state and even at times celebrating resistance to state hegemony. Second, legal pluralism often had an implicit pro-local bias, particularly in its emphasis on forms of resistance to colonial state hegemony. Perhaps echoing cultural anthropology's more general celebration of the local, legal pluralists tended to make the local, the indigenous, and the anti-colonial the heroes of the narrative.

6. See Wibren Van Der Burg, The Dynamics of Law and Morality: A Pluralist ACCOUNT OF LEGAL INTERACTIONISM 98-105 (2016) (drawing on theorist Lon Fuller to develop a theory of interactional law).

7. See, e.g., John Griffiths, What Is Legal Pluralism?, 24 J. Legal Pluralism \& UnOFficial L. 1 (1986) (critiquing the "ideology of legal centralism"). 
Nevertheless, even if we grant these implicit value preferences, legal pluralists, following most social scientists, generally have eschewed the sorts of strong normative arguments law professors routinely make: because of such-and-such research, we should now change legal or governmental systems in these particular ways. And there are surely virtues in focusing on thick description rather than normative prescription. Among other things, the constant pressure to produce "useful" work that will appeal to judges and policy-makers ${ }^{8}$ often forces legal academics into overly strong normative claims based on little evidence or an incomplete understanding of the complexity at work in social forces. One yearns for more effort to comprehend reality before switching to how best to reform it.

And yet...

I'd like to conduct a thought experiment. What might it mean for legal pluralists to play out some of the normative implications of their work for theories of law, policy, and institutional design? Do legal pluralists have something distinctive to add to contemporary law and governance debates? Or would asking such questions ultimately undermine the core insights of legal pluralism by committing scholars to particular modes of governance hierarchy? And if it did, is that a trade-off we can bear as scholars in exchange for policy relevance? And even if we were willing to make such a trade-off, is a legal pluralist position inherently in tension with any effort at systemic reform because legal pluralism recognizes that any system will always be partial, contested, and contingent? Or might systemic reform that is partial, contested, and contingent nevertheless be better than no reform at all? These are the questions I wish to ask here.

Most fundamentally, I believe legal pluralists might be able to mount a clearthroated defense of legal rules and governance institutions that foster interaction and dialogue among those multiple norm-generating communities rather than dissolving diversity either into universalism, on the one hand, or tribalism, on the other. And we need that defense right now, if only to name the values of diversity, dialogue, and communication across difference that are at the core of the world we might be on the brink of losing.

My thought experiment begins with a brief summary of global legal pluralism's descriptive project and why it better captures how law actually operates in the world than the traditional view offered by liberal legalism. Interestingly, legal pluralism's descriptive account of law is now far less controversial than it once was, which in and of itself is an important advance. But then I ask whether we might push the envelope farther and think of legal pluralism as a normative project as well, one specifically aimed at identifying those procedures, institutions, and practices that provide frameworks for managing diversity without dissolving it into universality. And although managing diversity is in some sense also the goal of liberal legality, it may be that legal pluralism offers a distinctive and perhaps sometimes a more

8. Austin Sarat \& Susan Silbey have called this pressure the "pull of the policy audience." Austin Sarat \& Susan Silbey, The Pull of the Policy Audience, 10 L. \& POL’Y 97 (1988). 
effective approach. In order to construct such an approach, I consider various ways in which we might manage encounters with others, and I use Hannah Arendt's model of "bearing with strangers" to think of how law might also build models of dialogue across difference rather than either walling difference off, on the one hand, or dissolving difference altogether, on the other. Next, I develop a set of principles that might be built into legal procedures, institutions, and practices that take seriously this pluralist approach. Finally, I draw on my own previous work to briefly summarize how such principles could actually be incorporated into legal institutions.

In the end, it is clear that no legal or governance system will ever gain universal acquiescence. And legal pluralists, of all people, recognize that. So, the relevant normative question becomes whether we can create procedural mechanisms, institutions, and discursive practices that build dialogue across difference into the DNA of whatever legal or governance structure is being considered. And that is a normative project that legal pluralists are well-positioned to champion.

\section{Global Legal Pluralism As a Descriptive Project}

As a descriptive matter, global legal pluralism, like legal pluralism generally, represented an important alternative to liberal legalism. Pluralists, of course, are far more likely than traditional liberals even to notice the pluralism of legal and quasi-legal norms that exist apart from the state. After all, most liberal theorists begin their analysis with the state: how it is formed, how it is justified, and the philosophical underpinnings for its operations. Non-state actors are surely important to this inquiry in that they clash with the liberal state, and of course the state, under liberalism, should often reach positions of accommodation with these non-state actors. But what is being described is fundamentally the state and how it views the non-state.

In contrast, pluralism assumes that the relevant inquiry is the entire range of legalities that course through the everyday experience of people. This means that the lived reality of communities and day-to-day perceptions of legitimacy and efficacy are far more important than philosophical models. In addition, a pluralist perspective is more likely to see individuals and groups, rather than just the state, as having agency and therefore playing crucial roles in navigating the interaction of normative systems and using those systems strategically.

For example, in the classic colonial interaction, a quasi-liberal, state-based legality was layered on top of an indigenous legal system. A liberal theorist would focus on the newly imposed system and on how it either accommodated or refused to accommodate local communities. In contrast, pluralists would observe that the colonial system rarely, if ever, wipes out the indigenous system altogether, and they would then focus on the interaction of these legal systems and the ways in which local actors use both systems strategically to gain leverage.

This is only one of many possible examples. But the point is that where liberalism only sees state legal systems and the challenges they face, pluralists focus 
on interactions among legal systems. And global legal pluralism recognizes that nation-states must work within a framework of multiple overlapping jurisdictional assertions by state, international, and non-state communities. Each of these types of overlapping jurisdictional assertions creates a potentially hybrid legal space that is not easily eliminated and therefore creates contexts for yet more interactions.

Just as important, pluralists are much less likely to insist on positivist definitions of law and are therefore more willing to notice law even in the absence of coercive power. This is especially significant in the global arena where statements of legal norms may be highly effective regardless of formal enforcement power. ${ }^{9}$ For example, liberal sovereigntists sometimes insist that international, transnational, and non-state legal norms have no independent valence and that instead states simply pursue their own interests. ${ }^{10}$ In contrast, pluralists unpack the idea of a state interest, recognizing that conceptions of proper policy do not simply arise in a vacuum. Rather, they are developed by human beings operating with various sets of assumptions, ideas about justice, conceptions of global strategy, and beliefs about morality. These assumptions, ideas, and cognitive categories are themselves shaped in part by what socio-legal scholars have long termed legal consciousness. Accordingly, the legal norms that are "in the air" at any given moment of historyincluding international, transnational, and non-state legal norms-may well affect how both policy makers and ordinary citizens think about the state's interests. ${ }^{11}$

Thus, legal pluralism provides a richer account of how law actually operates, both domestically and internationally, than the positivist vision of sovereigntism. We imbibe legal norms and cognitive categories even when we are not consciously aware of the norm in question. We are persuaded by legal norms even when those norms are not literally enforceable. We act in accordance with law because doing so has become habitual, not necessarily because we seek to avoid sanction. We conceive of our interrelations with others in terms of law because our long-term interests require that we do so, even when our short-term interest might seem to counsel otherwise. And the existence of a legal norm alters the constitutive terms of our relationships with others as well as the costs of noncompliance. All of these factors may be overcome in some circumstances. But the mere fact that legal norms are sometimes violated doesn't mean that those norms have no constraining force at all. And only by thinking more broadly about changes in legal consciousness and the complicated social, political, and psychological factors that enter into the conceptualization of state interests can we begin to understand how non-state law operates.

9. E.g., JutTa Brunnée \& Stephen J. ToOpe, Legitimacy AND Legality in INTERNATIONAL LAW: AN INTERACTIONAL ACCOUNT (2010) (describing the ability of legal norms to promote adherence even in the absence of enforcement mechanisms).

10. See generally JACK L. GOLDSMith \& ERIC A. POSNER, THE Limits of International LAW (2005).

11. Paul Schiff Berman, Seeing Beyond the Limits of International Law, 84 TEx. L. REV. 1265 (2006) (reviewing GOLDSMITH \& POSNER, supra note 10). 
In addition, instead of treating the state as a unitary "personality" with a single set of interests, pluralists recognize that the real world is far messier, with a vast number of constituencies both within the governmental bureaucracy and outside it. This cacophony of voices is important because many of these voices, when advocating policy positions, can use the moral authority or persuasive power of international, transnational, and non-state norms for leverage. These norms therefore become a tool of empowerment for particular actors. And given that any state policy decision is inevitably the result of a contest among various bureaucratic power centers, all of which are themselves influenced by outside pressure groups, lobbyists, NGOs and the like, a more complex understanding of the global legal arena would need to explore ways in which plural legal norms empower specific interests both within and without the state policy-making apparatus.

In short, global legal pluralism offers a more complicated descriptive account of the interaction of normative systems, the strategic action of individuals and groups in deploying these multiple systems to pursue their interests, and the subtle processes by which even norms without coercive power can change legal consciousness and have impact over time. These nuances are often elided in the traditional liberal legal analysis.

\section{From DESCRIPTIVE TO NORMATIVE}

Interestingly, as a descriptive enterprise, global legal pluralism is now quite uncontroversial (which I actually see as a great victory). Even the most die-hard legal positivist would now likely acknowledge that sub-, supra-, or non-state normative systems do impose real constraints that have real impacts. Thus, legal pluralists might be tempted simply to declare victory on the thick description front and stop there.

And yet ...

If I think back to why I was first attracted to cultural anthropology as an undergraduate major it was more than the fact that it offered a richer descriptive account of the world. I was drawn to its celebration of possibility. If "the way things are" is not natural and inevitable, but instead culturally constructed and contingent, then that means alternatives are open to us. Likewise, legal pluralism is also in some sense a fundamental celebration of the values of diversity, multiplicity, compound and flexible identities, and resistance to the seemingly natural state of things.

Consider the philosopher Iris Marion Young's idea of "unassimilated otherness," which she posited as the relation among people in the ideal "unoppressive city."12 Young envisioned ideal city life as the "'being-together' of strangers." 13 These strangers may remain strangers and continue to "experience

12. See Iris Marion Young, The Ideal of Community and the Politics of Difference, in FEMINISM/POSTMODERnism 300, 317 (Linda J. Nicholson ed., 1990) ("Our political ideal is the unoppressive city.").

13. Id. at 318 
each other as other."14 Indeed, they do not necessarily seek an overall group identification and loyalty. Yet, they are open to "unassimilated otherness." 15 They belong to various distinct groups or cultures and are constantly interacting with other groups. But, they do so without seeking either to assimilate or to reject those others. Such interactions instantiate an alternative kind of community, ${ }^{16}$ one that is never a hegemonic imposition of sameness but that nevertheless prevents different groups from ever being completely outside one another. ${ }^{17}$ In a city's public spaces, Young argues, we see glimpses of this ideal: "The city consists in a great diversity of people and groups, with a multitude of subcultures and differentiated activities and functions, whose lives and movements mingle and overlap in public spaces." 18 In this vision, there can be community without sameness, shifting affiliations without ostracism.

This is the idealism I believe is at the core of global legal pluralism. And yet at this moment in history, that precise set of ideals is under attack. Indeed, if states can be hegemonic and oppressive, it seems clear that nationalists can be even more so. In Europe, we see a pushback against the loose integration of the European Union (EU) in favor of tribalism. This is particularly troubling because the decades since 1945 have been by far the most peaceful and economically prosperous in Europe's many centuries of history, and we should not allow the governance pluralism that characterizes the EU to be lightly tossed aside because of vague calls for border protection and nation-state sovereignty. At the same time, worldwide we see communities refusing to allow increased migration and diversification, and instead calling for more stringent policing of borders, the building of walls, and so on. And of course religious intolerance and sectarian prejudice fuels numerous conflicts around the world. Most recently, Donald Trump's assault on all the institutions of democratic governance and the rise of the far right in Europe represent existential threats to the post World War II order and perhaps the ideal of democratic multiculturalism itself. All of these realities seem to me anathema to the pluralist project that called me to this field of study in the first place.

Given this context, I feel that it is incumbent on me as an actor in the world to do more than just describe. I feel the need to engage with the flight from the ideals of diversity I see around us and to make the case for institutions that, however imperfectly, embed pluralist ideals and values into their design. And so, in the

14. $I d$.

15. Id.

16. Young resists using the word "community" because of the "urge to unity" the term conveys but acknowledges that "[i]n the end it may be a matter of stipulation" whether one chooses to call her vision "community." Id. at 320. See also Jerry Frug, The Geography of Community, 48 STAN. L. REV. 1047, 1049 (1996) ("Unlike Young, I do not cede the term community to those who evoke the romance of togetherness.").

17. See Young, supra note 12, at 319 (positing that a group of strangers living side by side "instantiates social relations as difference in the sense of an understanding of groups and cultures that are different, with exchanging and overlapping interactions that do not issue in community, yet which prevent them from being outside of one another").

18. Id. 
remainder of this thought experiment, I am going to pursue what it might look like to think of global legal pluralism as an explicitly normative project.

As a normative project, legal pluralism can be seen to support two different possible strategies. First, a proceduralist vision of legal pluralism aims to design procedural mechanisms, institutions, and discursive practices that seek to manage pluralism, without making a priori substantive decisions regarding when deference to alternative norms is appropriate and when it is not. Second, what we might call substantive legal pluralism seeks the best ways to accommodate, celebrate, and/or assimilate non-majoritarian populations and norms. Substantive legal pluralism is fundamentally a multiculturalist project and therefore shares strengths and weaknesses of multiculturalist political philosophy. Accordingly, I will focus more on the proceduralist vision, while offering a few tentative thoughts on substantive legal pluralism as well. Principally, I will defend the proceduralist vision of legal pluralism as a potentially useful design principle in creating legal and political institutions, procedural mechanisms, and governmental and non-governmental practices.

\section{LEGAL PLURALISM AND THE IDEA OF COMMUNICATION ACROSS DIFFERENCE}

If we start from the descriptive reality of legal pluralism - a world of inevitable interaction among multiple communities, normative stances, and legal regimesthe operative question becomes: how might legal and governance systems respond to such a descriptive reality?

This normative question leads in turn to fundamental questions about communication across difference, the reality of pluralism. Might we say that there are more desirable or less desirable ways to communicate across difference?

So, then we can ask: How might we encounter the Other? How do we experience those who are different? Can we communicate? Can we live in parallel? Can we learn from those who are different? Can we ignore them? How do we manage the inevitable jostling that may arise? These are questions that are simultaneously psychological, sociological, political, and legal and, therefore, should be addressed on many different levels at once.

One possible response to the encounter with the Other is to focus on those attributes that make the Other not so different at all. This is the "we're all fundamentally the same" gambit we hear so often. And, interestingly, this focus on sameness can be adopted both by die-hard nationalists-who use it to insist that "our" norms (whoever the "our" might be) should govern all—and committed universalists, who use it to push for uniform norms operating cross-culturally throughout space and time.

In this same vein, some sociological studies of communication start from the idea that interpersonal interaction requires both parties in an encounter to believe 
(or at least assume) that the Other is not truly Other at all. ${ }^{19}$ According to this view, most associated with Alfred Schutz, differences in individual perspectives are overcome only if each party tacitly believes that he or she could effectively trade places with the other. As Schutz describes it, "I am able to understand other people's acts only if I can imagine that I myself would perform analogous acts if I were in the same situation[.]"20 Thus, differences in perspective are reduced to differences in situation. Any, possibly more fundamental, differences are suppressed to facilitate dialogue.

As a result, the deliberate assuming away of the unfamiliar is seen as a constant part of everyday life. The unfamiliar is relegated to the category of "strange," and "strangeness" necessarily is placed elsewhere, somewhere other than the interaction at hand. ${ }^{21}$ Indeed, Harold Garfinkel and other ethnomethodologists have argued that individuals do not simply passively maintain these assumptions but are constantly engaged in a joint enterprise aimed at sustaining this familiarity. ${ }^{22}$ In all of these studies, the emphasis is on "the human production of common worlds of meaning as the only axis on which dialogue rotates." 23

But is that all there is to the experience of the Other? Is it really imperative constantly to assume that our fellow human beings are fundamentally identical to us? After all, "[u]nder this principle, if a dialogue is to take place, strangeness as a phenomenon of everyday interaction must be considered negatively, namely, as that part of an encounter that must be constantly 'assumed away' by the participants." 24 Thus, we are left with a world in which people are classified either as familiar or as strangers. Even more problematic, these studies suggest that it will be simply impossible to bridge the communication gap with those deemed strangers. Yet, as Georg Simmel noted long ago, the stranger is never truly distant, ${ }^{25}$ so there will need to be some way of bridging gaps short of assuming away strangeness altogether.

On the other hand, we might respond to such encounters with the Other by retreating to a gated community and trying to lead a hermetically sealed existence. Here, the Other remains fully Other, and no communication is possible.

19. See generally Z.D. Gurevitch, The Other Side of Dialogue: On Making the Other Strange and the Experience of Otherness, 93 AM. J. SOC. 1179 (1988) (criticizing the idea that mutual understanding and communication in interpersonal communications is contingent on assuming commonality between Self and Other).

20. Alfred Schutz, On Phenomenology and Social Relations 181 (Helmut R. Wagner ed., 1970).

21. Gurevitch, supra note 19, at 1180 (summarizing arguments in ALFRED SCHUTZ, Collected Papers I: THe Problem of Social Reality (Maurice Natanson ed., 1962)).

22. See, e.g., Harold Garfinkel, Studies of the Routine Grounds of Everyday Activities, 11 SOC. PROBS. 225 (1964).

23. Gurevitch, supra note 19, at 1180.

24. Id. at $1181-82$.

25. See e.g., GEORG Simmel, The Stranger, in THe Sociology OF GEORG Simmel 402 (Kurt H. Wolff ed., 1950). 
Both of these responses, when translated to law, are fundamentally "jurispathic." 26 They kill off competing interpretations by authoritatively saying that this is the law and that is not. So, either a single nation-state's norms govern, or one universal law governs. Such jurispathic legal assertions may sometimes be effective, necessary, or desirable, but they are not the only ways to structure legal relations among multiple communities. Indeed, they both represent a fundamental retreat from pluralism. Yet, pluralism is difficult to escape in a world of overlapping jurisdictions and normative diversity, where-as the classic formulation goesmultiple conflicting legal systems occupy the same social field. The question therefore becomes: are there other approaches to managing pluralism? Can we develop a more pluralist governance approach? What are the institutional or procedural or discursive principles we might apply?

Unlike the universalist approach, a pluralist vision does not require people to be conceptualized as fundamentally identical in order to be brought within the same normative system. Nor does a pluralist vision render outsiders irrelevant, as sovereignist territorialism does. Instead, pluralism attempts to navigate a different path altogether. A pluralist frame asks whether we can seek solutions without assuming commonality or seek harmonization while preserving the insistence on difference that contextualists rightly emphasize. In short, pluralism questions whether we are doomed either to require commonality or to essentialize difference. Are those truly the only possible approaches?

Think again of how we encounter a stranger. Do we necessarily see that stranger only in binary terms, either as fundamentally the same as we are or as fundamentally different? Might not we see (and celebrate) important differences while seeking ways to bridge those gaps so that we might communicate with each other and live peaceably side by side?

Perhaps we might draw from Hannah Arendt, who offers a different way of conceptualizing the encounter with the stranger. Instead of assuming commonality, she seeks, in Understanding and Politics, the quality that "makes it bearable for us to live with other people, strangers forever, in the same world, and makes it possible for them to bear with us." 27 Note that for Arendt, the task is how to "bear with" strangers, even while recognizing that they will forever be strange. ${ }^{28}$ Arendt's strategy for bearing with strangers is more than just mutual indifference and more than just toleration as well. It "involves a mental capacity appropriate for an active relation to that which is distant," 29 which Arendt locates in King Solomon's gift of

26. See Robert M. Cover, The Supreme Court, 1982 Term-Foreword: Nomos and Narrative, 97 HARV. L. REV. 4, 53 (1983) (describing judges as "jurispathic" because their interpretations "kill" off competing normative assertions).

27. HANNAH ARENDT, Understanding and Politics (The Difficulties of Understanding), in ESSAYS IN UNDERSTANDING: 1930-1954, at 307, 322 (Jerome Kohn ed., 1994).

28. In focusing on Arendt's idea of "bearing with strangers," I draw from the analysis in Phillip Hansen, Hannah Arendt and Bearing with Strangers, 3 CONTEMP. POL. THEORY 3 (2004).

29. Id. at 3 . 
the "understanding heart." 30 Understanding, according to Arendt, "is the specifically human way of being alive; for every single person needs to be reconciled to a world into which he was born a stranger and in which, to the extent of his distinct uniqueness, he always remains a stranger." 31 What does "understanding" entail for Arendt? This is a bit difficult to pin down, but she makes clear that understanding is not gained through direct experience of the Other, and it is not just knowledge of the Other. ${ }^{32}$ Instead, understanding starts from the individual situated apart from others. Thus, instead of "feeling your pain," understanding involves determining what aspects of the pain people feel have to do with politics and "what politics can do to resolve our common dilemmas." 33 Moreover, " $[\mathrm{u}]$ nderstanding can be challenged and is compelled to respond to an alternative argument or interpretation." 34 In short, understanding in Arendt's formulation looks a lot less like empathy and a lot more like judging. ${ }^{35}$

While assuming sameness leads to a universalist harmonization approach, Arendt's more distanced conception of the encounter with the stranger is akin to the pluralist vision I am pursuing as an alternative. This is also Young's conception of "unassimilated otherness," in the ideal "unoppressive city." 36 It is the "'being-together' of strangers." 37

\section{BUILDING A Normative Global LEgal PluRAlism}

With this alternative frame in mind, here's an initial cut at translating such a pluralist vision into an overarching normative approach, one that seeks a middle ground between sovereigntist territorialism and tribalism on the one hand and universalism on the other. In this vision, the relevant question becomes: How might legal, governmental, or non governmental systems seek to create or preserve spaces for productive interaction among multiple, overlapping communities and legal systems by developing procedural mechanisms, institutions, and practices that aim to bring those communities and systems into dialogue rather than dictating norms hierarchically?

This question implies a set of principles for institutional design. Significantly, these principles are not derived from any overarching universal set of truths and do not require a commitment to universalism. They only require a pragmatic willingness to engage with other possible normative systems and potentially to restrain one's own jurispathic voice for the sake of forging more workable, longerlasting relationships and harmony among multiple communities. Sometimes, of course, such deference to the Other will not be possible; a proceduralist vision of

30. ARENDT, supra note 27 , at 322 .

31. Id. at 308.

32. See id. at 313 .

33. Jean Bethke Elshtain, Judging Rightly, 47 FIRST THINGS 49, 49 (1994) (reviewing ARENDT, supra note 27).

34. Id.

35. See ARENDT, supra note 27, at 313.

36. Young, supra note 12.

37. Id. at 318 . 
legal pluralism only seeks to embed habitual practices in which deference is considered and attempted, not in which it is always implemented. Let's see what some of these institutional principles might be.

First, a more pluralist approach to managing hybrid legal spaces should not attempt to erase the reality of that hybridity. Indeed, arguably the desire to "solve" hybridity problems is precisely what has made conflict of laws such a conceptually unsatisfying field for so long. Each generation seeks a new way (or often the revival of an old way) to divine an answer to what is at its root an unanswerable question: which territorially based state community's norms should govern a dispute that, by definition, is not easily situated territorially and necessarily involves affiliations with multiple communities?

Second, a pluralist framework recognizes that normative conflict is unavoidable and so, instead of trying to erase conflict, seeks to manage it through procedural mechanisms, institutions, and practices that might at least draw the participants to the conflict into a shared social space. This approach draws on Ludwig Wittgenstein's idea that agreements are reached principally through participation in common forms of life, rather than through agreement on substance. ${ }^{38}$ Or, as the political theorist Chantal Mouffe has put it, we need to transform "enemies" - who have no common symbolic space-into "adversaries." 39 Adversaries, according to Mouffe, are "friendly enemies": friends because they "share a common symbolic space but also enemies because they want to organize this common symbolic space in a different way." 40 Ideally, law-and particularly pluralist legal mechanisms-can function as the sort of common symbolic space that Mouffe envisions and can therefore play a constructive role in transforming enemies into adversaries. This is akin to Young's ideal city.

Of course, Mouffe might well disagree with my application of her idea to law. Indeed, in The Democratic Paradox, she writes that "one cannot oppose, as so many liberals do, procedural and substantial justice without recognizing that procedural justice already presupposes acceptance of certain values." certainly, my focus on procedural mechanisms, institutions, and practices necessarily limits the range of pluralism somewhat because it requires participants to accept the principles underlying the values of procedural pluralism itself. This is, to a large extent, a vision consonant with liberal principles, and many may reject it on that basis. Alas, there is no way to extricate oneself from this concern if one wants to have any type of functioning legal system for negotiating normative difference. Thus, I argue only that a pluralist framework is more likely to draw participants together into a common social space than a territorialist or universalist framework would. As philosopher Stuart Hampshire has argued, because normative

38. Ludwig Wittgenstein, Philosophical InVestigations para. 241, at 88 (G.E.M. Anscombe trans., 3d ed. 1967).

39. Chantal Mouffe, The Democratic Paradox 13 (2000).

40. $I d$.

41. Id. at 68 . 
agreement is impossible, "[f]airness and justice in procedures" are the only virtues that offer even the possibility for broader sharing. ${ }^{42}$ Accordingly, the key is to create spaces for such broader sharing, spaces for turning enemies into adversaries, without insisting on normative agreement. ${ }^{43}$

Third, to help create this sort of shared social space, procedural mechanisms, institutions, and practices for managing pluralism should encourage decisionmakers to wrestle explicitly with questions of multiple community affiliation and the effects of activities across territorial borders, rather than shunting aside normative difference. As a result, a pluralist framework invites questions that otherwise might not be asked: How are communities appropriately defined in today's world? To what degree do people act on the basis of affiliations with nonstate or supranational communities? How should the various norm-generating communities in the global system interact so as to provide opportunities for contestation and expression of difference? Such questions must be considered carefully to develop mechanisms that will take seriously the multifaceted interactions of such communities.

Thus, a pluralist conception makes no attempt to deny the multi-rooted nature of individuals within a variety of communities, both territorial and nonterritorial. Accordingly, although a pluralist conception might acknowledge the potential importance of asserting universal norms in specific circumstances, it does not require a universalist belief in a single world community. As a result, pluralism offers a promising rubric for analyzing law in a world of diverse normative voices.

Fourth, thinking in pluralist terms forces consideration of values inherent in a smoothly functioning trans-community legal order, what Justice Blackmun called "the systemic value of reciprocal tolerance and goodwill." 44 For example, in the United States, courts give full faith and credit to judgments rendered in other states even if those judgments could never have been issued by the crediting state. ${ }^{45}$ Thus, the value of respecting an interlocking national system outweighs the individual parochial interests of the crediting state. Such considerations should always be part of any mechanism for addressing the overlap of plural legal systems. Moreover,

42. STUART HAMPSHIRE, JUSTICE IS CONFLICT 53 (2000).

43. Cf. Jeremy Waldron, Tribalism and the Myth of the Framework, in KARL POPPER: CRITICAL APpraisals 203, 221 (Philip Catton \& Graham Macdonald eds., 2004) ("Humans are enormously curious about each other's ideas and reasons, and, when they want to be, they are resourceful in listening to and trying to learn from one another across what appear to be barriers of cultural comprehensibility, often far beyond what philosophers and theorists of culture give them credit for.").

44. Société Nationale Industrielle Aérospatiale v. U.S. Dist. Court, 482 U.S. 522, 555 (1987) (Blackmun, J., concurring in part and dissenting in part).

45. See, e.g. Estin v. Estin, 334 U.S. 541, 545 (1948) (stating that the Full Faith and Credit Clause "ordered submission ... even to hostile policies reflected in the judgment of another State, because the practical operation of the federal system, which the Constitution designed, demanded it"). See also Milwaukee Cty. v. M.E. White Co., 296 U.S. 268, 277 (1935) ("In numerous cases this court has held that credit must be given to the judgment of another state, although the forum would not be required to entertain the suit on which the judgment was founded[.]"); Fauntleroy v. Lum, 210 U.S. 230, 237 (1908) (stating that the judgment of a Missouri court was entitled to full faith and credit in Mississippi even if the Missouri judgment rested on a misapprehension of Mississippi law). 
taking account of these sorts of systemic values should be seen as a necessary part of how communities pursue their interests in the world, not as a restraint on pursuing such interests. After all, if it is true that communities cannot exist in isolation from one another, then there is a long-term parochial benefit from not insisting on narrow parochial interest and, instead, establishing mechanisms for trying to defer to others' norms where possible.

Fifth, even a system that respects such inter-systemic values will, of course, sometimes find a particular foreign norm to be such an anathema that the norm will not be enforced. ${ }^{46}$ Or, a local religious practice may be so contrary to state values that it will be deemed illegal. ${ }^{47}$ Or, creating a zone of autonomy for a particular minority group might so threaten the stability of the larger community that it cannot be countenanced. Thus, embracing pluralism in no way requires a full embrace of illiberal communities and practices or the recognition of autonomy rights for every minority group across the board. But when such "public policy" exceptions are invoked within a pluralist framework, they should be treated as unusual occasions requiring strong normative statements regarding the contours of the public policy. ${ }^{48}$ This means that, as Robert Cover envisioned, a jurispathic act that "kills off" another community's normative commitment is always at least accompanied by an equally strong normative commitment. ${ }^{49}$ The key point is to make decision-makers self-conscious about their sometimes necessary jurispathic actions. ${ }^{50}$ Only such an approach has any chance of preventing adversaries from turning into enemies.

Finally, a pluralist framework must always be understood as a middle ground between tribalism, on the one hand, and universalism, on the other. The key, therefore, is to try to articulate and maintain a balance between these two poles. As such, successful mechanisms, institutions, or practices will be those that simultaneously celebrate both local variation and international order, and recognize the importance of preserving both multiple sites for contestation and an interlocking system of reciprocity and exchange. Of course, actually doing that in difficult cases is a Herculean and perhaps impossible task. Certainly, mutual

46. For example, a liberal legal order might refuse to enforce a judgment issued by an authoritarian ruler or a court system that does not adhere to fundamental norms of due process.

47. For example, a religious practice that violates fundamental norms of equality may get less deference from a liberal legal order than one that does not.

48. See, e.g., Convention on the Recognition and Enforcement of Foreign Arbitral Awards, June 10, 1958, 21 U.S.T. 2517, 330 U.N.T.S. 38 (requiring courts to enforce the judgment or arbitral award unless the agreement is null and void, inoperative, incapable of being performed, or if enforcing it would be repugnant to the public policy of the enforcing forum).

49. See Cover, supra note 26 (describing judges as inevitably "people of violence" because their interpretations "kill" off competing normative assertions).

50. See Judith Resnik, Living Their Legal Commitments: Paideic Communities, Courts, and Robert Cover (An Essay on Racial Segregation at Bob Jones University, Patrilineal Membership Rules, Veiling, and Jurisgenerative Practices), 17 YALE J.L. \& HumAN. 17, 25 (2005) ("[Cover] wanted the state's actors . . . to be uncomfortable in their knowledge of their own power, respectful of the legitimacy of competing legal systems, and aware of the possibility that multiple meanings and divergent practices ought sometimes to be tolerated, even if painfully so."). 
agreement about contested normative issues is unlikely and, as discussed previously, possibly even undesirable. Thus, the challenge is to develop ways to seek mutual accommodation while keeping at least some "play" in the joints so that diversity is respected as much as possible. Such play in the joints also allows for the jurisgenerative possibilities inherent in having multiple lawmaking communities and multiple norms. ${ }^{51}$ Always, the focus is on trying to forge the sort of shared social space that Mouffe describes for transforming enemies into adversaries and Young describes as the ideal city.

Taken together, these principles provide a set of normative criteria for evaluating the ways in which legal systems interact. In addition, the principles could inform a community (whether state-based or not) that wishes to design mechanisms, institutions, or practices for addressing plural assertions of norms. Of course, as discussed above, such criteria are not exclusive. For example, a procedure or practice that manages pluralism well but denies certain norms of fundamental justice might be deemed problematic, regardless of its embrace of pluralism. Thus, my goal is not to say that embracing pluralism always overrides other concerns. After all, as mentioned previously, many legal and quasi-legal orders are repressive and profoundly illiberal, and their norms may be resisted on those grounds. Instead, the important point is simply that pluralist considerations should always at least be part of the constitutional design, inculcating habits of mind that promote deference and restraint. Accordingly, decision-makers should always ask: Are there other normative systems at play here? Should I restrain my jurispathic voice? Is there some other decision-maker who might more appropriately speak to this issue? Are there ways I could develop a hybrid decisional framework that brings more voices to the table? And how can I design ongoing practices, procedures, or institutional arrangements to constitutionally embed these inquiries?

\section{Six MeChanisms For MANAgING LEgAL PluRALISM}

\section{A. Dialectical Legal Interactions}

If the idea of managing, without eliminating, pluralism is your frame, then projects like the European Union become not a failure (as we often hear), but something closer to the ideal, at least in conception if not in every detail. Indeed, while universalists complain that Europe should have a stronger commitment to centralized solutions and nation-state sovereigntists complain that Belgian bureaucrats threaten state autonomy, a normative vision of legal pluralism suggests that the EU's institutional apparatus has important benefits in its balance of both positions and its efforts to accommodate both universalism and sovereigntist territorialism at the same time.

51. See Seyla Benhabib, Another Cosmopolitanism 49 (Robert Post ed. 2006) (discussing and defining "jurisgenerative processes"). 
Thus, while constitutions traditionally try to demarcate clear hierarchical lines of authority among different decision-makers, a more pluralist constitutional design might, instead, create increased opportunities for dialectical legal interactions. For instance, as noted previously, some who study international law fail to find real "law" in the international realm because they are looking for hierarchically based commands backed by coercive power. ${ }^{52}$ In contrast, a pluralist approach understands that interactions among various tribunals and regulatory authorities are more likely to take on a dialectical quality that is neither the direct hierarchical review traditionally undertaken by appellate courts, nor simply the dialogue that often occurs under the doctrine of comity. ${ }^{53}$

Consider, for example, interactions between the European Court of Human Rights (ECHR) and the constitutional courts of European member states. Here, the relationship may seem hierarchical because, over the past several decades, the ECHR has increasingly come to seem like a supranational constitutional court, and its authority as ultimate arbiter of European human rights disputes has largely been accepted. ${ }^{54}$ Yet, even in this context there appears to be more room for pluralism than is typical in hierarchical legal systems. As Nico Krisch has documented, domestic courts occasionally refuse to follow ECHR judgments, asserting fundamental principles embedded in their own constitutional order and, in general, claiming the power to determine the ultimate limits to be placed on the authority of the ECHR..$^{55}$ Typical of this dialectical relationship is the statement by the German Constitutional Court that ECHR judgments have to be "taken into account" by German courts but may have to be "integrated" or adapted to fit the domestic legal system. ${ }^{56}$ Moreover, the German Court has gone so far as to say that ECHR decisions must be disregarded altogether if they are "contrary to German constitutional provisions." 57

Yet, although such statements make it sound as if conflict between the ECHR and domestic courts is the norm, the reality has actually been quite harmonious. As Krisch points out, "despite national courts' insistence on their final authority, the normal, day-to-day operation of the relationship with the [ECHR] has lately been highly cooperative, and friction has been rare." 58 The picture that emerges is one in which domestic courts and the ECHR engage in a series of both informal and interpretive mutual accommodation strategies to maintain a balance between uniformity and dissention. Likewise, as Lisa Conant has observed, nation-state

52. See, e.g., GOLDSMITH \& POSNER, supra note 10.

53. See Robert B. Ahdieh, Between Dialogue and Decree: International Review of National Courts, 79 N.Y.U. L. REV. 2029 (2004), for a detailed analysis of such dialectical regulation.

54. See generally Nico Krisch, The Open Architecture of European Human Rights Law, 71 MOD. L. REV. 183 (2008) (discussing the evolution of the European human rights regime while tracing the interaction of the European Court of Human Rights with domestic courts in the European Union).

55. See generally id.

56. Id. at 196

57. Id. at $196-97$.

58. Id. at 197. 
courts have sought to "contain" the impact of European Court of Justice (ECJ) decisions on national legal orders, even while formally accepting both the supremacy of EU law and the ECJ's role in authoritatively interpreting that law. ${ }^{59}$ These sorts of dialectical relationships, forged and developed over many years, may well reflect a workable path for the many other intersystemic interactions at play in the world today.

For another example, consider the Canadian Constitution, which explicitly contemplates a dialectical interaction between national courts and provincial legislatures concerning constitutional interpretation. Section 33's so-called "notwithstanding" clause permits Parliament or a provincial legislature to authorize the operation of a law for a five-year period, even after it has been declared invalid by a court. ${ }^{60}$ As with the ECHR example, this provision potentially has a disciplining effect on the court and encourages a more nuanced iterative process in working out constitutional norms. It is true of course that the notwithstanding clause, though often invoked rhetorically, has only rarely actually been used by provincial governments to continue a judicially invalidated law. ${ }^{61}$ Yet, this relative infrequency of use may not be evidence of a failed constitutional innovation. Instead, it may indicate just the opposite: that the various institutional actors have sufficiently internalized this mechanism for managing hybridity such that, as in the ECHR example, the precipice is rarely reached. ${ }^{62}$

In contrast to the dialectical interplay contemplated by the "notwithstanding clause," the U.S. Supreme Court has, on multiple occasions, interpreted the U.S. Constitution to contain an implicit foreign affairs preemption doctrine that cuts off such interplay. ${ }^{63}$ For example, the Court has refused to allow localities to take

59. See Lisa CONANT, JUStice CONTAINED: LAW AND POLITICS IN THE EUROPEAN UNION 3 (2002).

60. See Canadian Charter of Rights and Freedoms, Part I of the Constitution Act, 1982, being Schedule B to the Canada Act 1982, c. 11, $₫ 33$ (U.K.).

61. For example, the Quebec Parliament overrode the Canadian Supreme Court's invalidation of provisions of a language law. See Ford v. Quebec, [1988] 2 S.C.R. 712 (Can.). However, outside Quebec the notwithstanding clause has never been used to overturn a judicial decision. See James Allan \& Grant Huscroft, Constitutional Rights Coming Home to Roost? Rights Internationalism in American Courts, 43 SAN DIEGO L. REV. 1, 21 (2006). In addition, according to one account, the clause has been disavowed by successive prime ministers because "[i] ts use has come to be seen as undermining the Charter, in part because judicial decisions interpreting the Charter have come to be seen as synonymous with the Charter itself." Id. at 20.

62. On the other hand, it is possible that "the notwithstanding clause frees Canadian courts to be less deferential to elected legislatures than they otherwise would have been in the absence of such a clause, because it allows judges to act on the basis that their decisions are not final." Allan \& Huscroft, supra note 61, at 21-22 (emphasis added). In any event, the important point for our purposes is that the clause is structured as a mechanism for managing the hybridity of multiple communities within a federal system. See Jennifer Nedelsky, Reconceiving Rights and Constitutionalism, 7 J. HUM. RTS. 139, 147-48 (2008), for an account supporting the approach of the notwithstanding clause from the perspective of political theory.

63. See, e.g., American Ins. Ass'n v. Garamendi, 539 U.S. 396 (2003) (striking down California law requiring insurance companies doing business in California to disclose any business activities in Europe during the Nazi Holocaust); Crosby v. Nat'l Foreign Trade Council, 530 U.S. 363 (2000) 
actions that were deemed to encroach upon the exclusive national prerogative to conduct foreign affairs. 64 Yet, one might think that "[in our] democratic federation... local efforts to effectuate protection of rights have a presumptive validity" authorized by the commitments to multiple voices protected in a federal system. ${ }^{65}$ At the very least, courts should carefully interrogate the claimed justification for preemption to ensure that the local action at issue poses a real, rather than conjectural, threat to the federal government's conduct. ${ }^{66}$ After all, pluralism is built into the structure of federalism, and so actions of localities to import international or foreign norms or signal solidarity with them should not easily be displaced.

Indeed, at times we can see the explicit creation of dialectical legal regimes to manage federalist interactions. For example, take California's efforts to impose more stringent automobile fuel efficiency standards than the federal government's standards ${ }^{67}$ At first glance, this might seem to be simply a direct state challenge to federal authority. However, the entire regime under which California can apply for a waiver to impose stricter standards is itself a creature of federal law because it is the Clean Air Act that grants California the special status in regulating automobile emissions ${ }^{68}$ and that arguably has contributed to California's regulatory leadership in this area. ${ }^{69}$ Similarly, the 1990 amendments to the Clean Air Act established a formal mechanism whereby northeastern states were granted the ability to cooperate in the control of ozone, but the Environmental Protection Agency (EPA) was given the power to approve or disapprove any recommendations the consortium might have. ${ }^{70}$

Significantly, these provisions, both of which explicitly create formalized dialectical (or multiscalar) relations between state and federal authority, may be preferable to a regime that grants either the states or the federal government sole

(prohibiting Massachusetts from banning state expenditures on goods and services from any person that had been in business with Burma); Zschernig v. Miller, 389 U.S. 429 (1968) (striking down Oregon statute that had the effect of preventing a resident of East Germany from inheriting property probated in the state); see also Judith Resnik, Foreign as Domestic Affairs: Rethinking Horizontal Federalism and Foreign Affairs Preemption in Light of Translocal Internationalism, 57 EMORY L.J. 31 (2007), for a discussion of these cases.

64. See supra note 63.

65. Resnik, supra note 50 , at 85 .

66. See id. at 87 (" $\mathrm{J}]$ udges ought to adopt a posture of non-encroachment by insisting on exacting evidence of particular and specific imminent harms before invalidating actions by localities or by states as those entities determine their own expenditures of funds and rules.”). (2009).

67. Ann E. Carlson, Iterative Federalism and Climate Change, 103 Nw. U. L. REv. 1097, 1128

68. See 42 U.S.C. $\$ 7543(\mathrm{e})(2)(\mathrm{A})(2006)$.

69. See Carlson, supra note 67, at 1109 (2009) (“California's leadership on climate change issues is not merely the product of state leadership. California's climate change regulations are a direct result of federal law, which has played a central role both in allowing the state to regulate and in demanding stricter regulation of air pollution.”).

70. See 42 U.S.C. $\int 7511$ c(a) (2012). 
authority. ${ }^{71}$ As Ann Carlson argues, the federal statutes have, as an initial matter, tended to encourage the states to ratchet up their environmental protection beyond what they otherwise might have done. ${ }^{72}$ However, the dialectical scheme has gone further and actually encouraged the deputized states to become leaders on environmental compliance. ${ }^{73}$ Moreover, by granting such authority to only one state or to a small group of states, the dialectical scheme reaps the benefits of permitting a greater field for experimentation than a top-down solution would ordinarily provide, while at the same time achieving greater national uniformity than would occur if each state were free to go its own way. Thus, the pluralist approach of these provisions walks a middle ground between fully decentralized and fully centralized power and arguably achieves a better outcome than either.

Likewise, the Sudan Accountability and Divestment Act of 2007 was a federal statute that authorized states to divest from companies doing business in Sudan, but only under certain conditions and in limited ways, and only until the President certified that the human rights abuses committed by Sudan have eased. ${ }^{74}$ Again, the federal restrictions addressed concerns about national uniformity in foreign affairs, but the Act did not embrace the jurispathic doctrine of foreign affairs preemption, under which the U.S. Supreme Court altogether foreclosed Massachusetts's efforts to divest from companies doing business in Burma. ${ }^{75}$ Instead, the pluralist approach of the statute provided a port of entry for states to contribute to the formulation of national foreign policy while guarding against complete devolution of foreign affairs power. As Perry Bechky observed:

$[S]$ tate divestment may call attention to an under-attended concern, influence societal attitudes about that concern, and build domestic political support for a more vigorous national response thereto. Congress may reasonably conclude that it wishes to hear state speech about Darfur as it continually reassesses the degree of priority to afford Darfur amongst the many concerns competing for Congressional attention. ${ }^{76}$

Accordingly, the statutory scheme provided greater opportunity for intersystemic dialogue, public debate, and creative norm generation by multiple actors than if either a localist or nationalist solution had fully triumphed.

These examples all involve dialectical interactions between formal state or international legal institutions. However, the same dialectical interactions are possible with regard to non-state normative standards. For example, the decisions of arbitral panels may, over time, exert influence on the decisions of more formal

71. See generally Hari M. Osofsky, The Future of Environmental Law and Complexities of Scale: Federalism Experiments with Climate Change Under the Clean Air Act, 32 WASH. U.J.L. \& POL'Y 79 (2010) (suggesting ways for these multiscalar approaches to evolve in light of changing environmental law demands).

72. See Carlson, supra note 67 , at $1100-01$.

73. See id. at 1101,1134-35.

74. See Sudan Accountability and Divestment Act of 2007, Pub. L. No. 110-174, 121 Stat. 2516.

75. See Crosby v. Nat'l Foreign Trade Council, 530 U.S. 363 (2000).

76. Perry S. Bechky, Darfur, Divestment, and Dialogue, 30 U. PA. J. INT’L L. 823, 826 (2009). 
state or international bodies, and vice versa. In a different context, states may incorporate or adapt standards of conduct that are part of accreditation schemes promulgated by nongovernmental organizations (NGOs) or industry groups, or industry standards promulgated by trade associations or other quasi-regulatory bodies. ${ }^{77}$ And more broadly, we might see the creation of monitoring schemes in general as a kind of pluralist approach because instead of dictating rules, such monitoring generates oversight and publicity that can instigate change without a formal hierarchical relationship or coercive enforcement.

\section{B. Margins of Appreciation}

One of the interpretive mechanisms employed by the ECHR to maintain space for local variation is the oft-discussed "margin of appreciation" doctrine. ${ }^{78}$ Unlike the dialectical legal encounter between the ECHR and the German Constitutional Court described above, the margin of appreciation doctrine is an explicit interpretive device employed by the ECHR to give play to local variation. The idea here is to strike a balance between deferring to national courts and legislators, on the one hand, and maintaining "European supervision" that "empower[s the ECHR] to give the final ruling" on whether a challenged practice is compatible with the European Convention on Human Rights, on the other. ${ }^{79}$ Thus, the margin of appreciation allows domestic polities some room to maneuver in implementing ECHR decisions in order to accommodate local variation. How big that margin is depends on a number of factors, including the degree of consensus among the member states. For example, in a case involving parental rights of transsexuals, the ECHR noted that because there was as yet no common European standard, and "generally speaking, the law appears to be in a transitional stage, the respondent State must be afforded a wide margin of appreciation." 80

Affording this sort of variable margin of appreciation usefully accommodates a limited range of pluralism. It does not permit domestic courts to ignore fully the supranational pronouncement (though, as discussed previously, domestic courts have sometimes asserted greater independence). Nevertheless, it does allow space for local variation, particularly when the law is in transition or when no consensus

77. See, e.g., Jody Freeman, The Private Role in Public Governance, 75 N.Y.U. L. REV. 543, 618-19 (2000) (describing government incorporation of accreditation standards on health maintenance organizations (HMOs) first promulgated by nongovernmental entities); see also LAURA A. DICKINSON, Outsourcing War and Peace: Preserving Public Values in a World of Privatized FOREIGN AFFAIRS 92-95 (2011) (proposing such an accreditation scheme for disciplining private military contractors).

78. See generally Laurence R. Helfer \& Anne-Marie Slaughter, Toward a Theory of Effective Supranational Adjudication, 107 YALE L.J. 273, 316-17 (1997), for a particularly useful, succinct summary. My discussion here largely tracks theirs.

79. Sunday Times v. United Kingdom, 2 Eur. H.R. Rep. 245, 276 (1979).

80. X v. United Kingdom, App. No. 21830/93, 24 Eur. H.R. Rep. 143, 144 (1997); see also OttoPreminger Inst. v. Austria, App. No. 13470/87, 19 Eur. H.R. Rep. 34, 57-58 (1994) (finding that the lack of a uniform European conception of rights to freedom of expression "directed against the religious feelings of others" dictates a wider margin of appreciation). 
exists among member states on a given issue. Moreover, by framing the inquiry as one of local consensus, the margin of appreciation doctrine disciplines the ECHR and forces it to move incrementally, pushing toward consensus without running too far ahead of it.

Finally, the margin of appreciation functions as a signaling mechanism, through which "the ECHR is able to identify potentially problematic practices for the contracting states before they actually become violations, thereby permitting the states to anticipate that their laws may one day be called into question." 81 And of course, there is reverse signaling as well, because domestic states, by their societal evolution away from consensus, effectively maintain space for local variation. As Laurence Helfer and Anne-Marie Slaughter have observed, "The conjunction of the margin of appreciation doctrine and the consensus inquiry thus permits the ECHR to link its decisions to the pace of change of domestic law, acknowledging the political sovereignty of respondent states while legitimizing its own decisions against them." 82 A similar sort of interaction could be established by a constitutional court adopting some form of the classic "concept versus conception" distinction ${ }^{83}$ with regard to the adoption of norms by other actors. Thus, an entity such as the ECHR could, for example, articulate a particular concept of rights while recognizing that the way this right is implemented is subject to various alternative conceptions.

Other legal regimes could also usefully adopt margins of appreciation. For example, the controversial agreement on Trade-Related Aspects of Intellectual Property Rights could be interpreted to incorporate a margin of appreciation. ${ }^{84}$ Such a flexible approach might allow developing countries more leeway in trying to make sure that access to knowledge in their countries is not unduly thwarted by overly stringent intellectual property protection.

\section{Subsidiary Schemes}

Subsidiarity is another mechanism for managing the interactions among different legal or quasi-legal authorities. The Catholic Church first developed subsidiarity as an ordering principle designed to prevent so-called higher levels of

81. Helfer \& Slaughter, supra note 78, at 317; see also Laurence R. Helfer, Consensus, Coberence and the European Convention on Human Rights, 26 CORNELL INT'L L.J. 133, 141 (1993). See J.G. Merrills, The Development of International Law by the European Court of HUMAN RigHTS 81 (2d ed. 1993) (interpreting the ECHR's statement in Rees v. United Kingdom, App. No. 9532/81, 9 Eur. H.R. Rep. 56, 68 (1986), that " [t] he need for appropriate legal measures [to protect transsexuals] should therefore be kept under review having regard particularly to scientific and societal developments" as a "strong hint that while British practice currently satisfied [the Convention], the Court's duty to interpret the Convention as a living instrument may lead it to a different conclusion in the future"), for an example of this type of signaling.

82. Helfer \& Slaughter, supra note 78, at 317.

83. See, e.g., RONALD DWORKIN, LAW'S EMPIRE 71 (1986) (discussing the difference between "concept" and "conception" as "a contrast between levels of abstraction at which the interpretation of the practice can be studied").

84. Agreement on Trade-Related Aspects of Intellectual Property Rights, Apr. 15, 1994, 33 I.L.M. 1197. 
authority from interfering unduly with the "internal life of a community." 85 But, here I am less interested in the idea of pushing decisions to the local level than I am in fostering in decision-makers habits of mind that cause careful and repeated consideration of other potential lawmaking communities. Thus, "at its core the principle of subsidiarity requires any infringements of the autonomy of the local level by means of pre-emptive norms enacted on the higher level to be justified by good reasons." 86 Accordingly, it is not enough for a national governance rule simply to be a good idea; the supranational lawmaking community also must consider whether the rule is one that is appropriately enacted at the supranational level, given contrary local policies.

For example, consider the case of a higher-level authority that enacts an emissions cap to combat global climate change but runs up against a lower-level authority that performed its own cost-benefit analysis and determined that it was better for the local economy not to create such a stringent restriction. ${ }^{87}$ Here, the collective action problems inherent in the lower-level authority's parochial costbenefit analysis would probably justify intervention at the higher level. In contrast, a higher-level rule limiting nicotine consumption, for example, might not override a more permissive local rule because the locality can plausibly decide it wants to bear the higher health care costs or other consequences that might result.

As with all mechanisms for managing pluralism, the line-drawing problems are potentially difficult and often politically contested, but even the habits of mind generated by thinking in terms of subsidiarity can help ensure that lawmaking communities at least take into account other potentially relevant lawmaking communities. ${ }^{88}$ Moreover, subsidiarity can help "local populations . . . better

85. See Catechism of the Catholic Church I 1883, HOLY SEE, http://www.vatican.va/ archive/ENG0015/__P6G.HTM [https://perma.cc/6PY2-Y4Z8] (last visited June 1, 2018) (“[A] community of a higher order should not interfere in the internal life of a community of a lower order, depriving the latter of its functions, but rather should support it in case of need and help to co-ordinate its activity with the activities of the rest of society, always with a view to the common good.") (quoting John Paul II, Centesimus Annus If 48 (May 1, 1991), available at http://www.vatican.va/ holy_father/john_paul_ii/encyclicals/documents/hf_jp-ii_enc_01051991_centesimus-annus_ en.html\#-2S [https://perma.cc/LM4R-G7DL]).

86. Mattias Kumm, The Legitimacy of International Law: A Constitutionalist Framework of Analysis, 15 EUR. J. INT’L L. 907, 921 (2004).

87. See $i d$. at $923-24$, for a similar hypothetical example.

88. I realize that my discussion of subsidiarity has a functionalist cast and therefore may seem to deemphasize other concerns, such as democratic legitimacy or the nation-state's claims to loyalty as against supranational institutions. See, e.g., Peter L. Lindseth, Democratic Legitimacy and the Administrative Character of Supranationalism: The Example of the European Community, 99 COLUM. L. REV. 628, 669 (1999) (arguing that a functionalist approach "is clearly inadequate to understanding the full import of the subsidiarity principle" because it tends to ignore important issues of legitimacy); Paul D. Marquardt, Subsidiarity and Sovereignty in the European Union, 18 FORDHAM INT’L L.J. 616, 618 (1994) (“[T] he underlying logic of subsidiarity reduces the claim of rightful governance to a technocratic question of functional efficiency that will eventually undercut the nationstate's claims to loyalty."). However, the sort of dialogue that mechanisms for managing hybridity encourage need not be "technocratic" and can in fact engage with precisely the questions of legitimacy and community ties that critics want. Thus, I argue only for mechanisms that enhance dialogue; I do 
preserve their sense of social and cultural identity" 89 while still allowing for the possibility that higher-level governmental authority might sometimes be necessary. Finally, even though a subsidiarity regime sets the default in favor of local decisions, requiring articulated justifications to override the presumption, subsidiarity-related concerns can sometimes actually strengthen the perceived legitimacy of the higherlevel authority. This is because, when the higher authority does override local regulation, it presumably does so only after carefully considering local practices and only after articulating reasons to justify such an override. ${ }^{90}$

Accordingly, the institutional processes of subsidiarity aim to ensure dialogue among multiple legal communities, leading ideally to increased acceptance of each. Not surprisingly, subsidiarity has been proposed as a more general model for international law as well. ${ }^{91}$ Indeed, the complementarity regime of the International Criminal Court-whereby the Court only takes jurisdiction if the local state is unwilling or unable to investigate ${ }^{22}$ — can be seen as a form of subsidiarity scheme.

\section{Hybrid Participation Arrangements}

Sometimes pluralism can be addressed not so much through the relationships among multiple communities and their decision-makers as through hybridizing the decision-making body or process itself. For example, from 1190 until 1870, English law used the so-called mixed jury, or jury de medietate linguae, with members of two different communities sitting side by side to settle disputes when people from the two communities came into conflict. ${ }^{93}$ Sir Edward Coke attributed this practice "to the Saxons, for whom 'twelve men versed in the law, six English and an equal number of Welsh, dispense justice to the English and Welsh."'94 Regional differences, however, were not the only type of community variation recognized in the mixed-jury custom. Mixed juries were also used in disputes between Jews and

not circumscribe the content of that dialogue. Nevertheless, to the extent that critics of a functionalist account of subsidiarity are trying to raise a sovereigntist objection to supranationalism in general, the pluralist framework I pursue here clearly rejects such a position as both normatively undesirable and impractical. See George A. Bermann, Taking Subsidiarity Seriously: Federalism in the European Community and the United States, 94 COLUM. L. REV. 331, 341 (1994).

89. See Bermann, supra note 88.

90. See Kumm, supra note 86, at 922 ("If there are good reasons for deciding an issue on the international level, because the concerns addressed are concerns best addressed by a larger community, then the international level enjoys greater jurisdictional legitimacy.”).

91. See, e.g., id. at 921-22. 1012.

92. Rome Statute of the International Criminal Court art. 17, July 17, 1998, 37 I.L.M. 1002,

93. Deborah A. Ramirez, The Mixed Jury and the Ancient Custom of Trial by Jury De Medietate Linguae: A History and a Proposal for Change, 74 B.U. L. REV. 777, 781 (1994); see also MARIANNE


CiTIZENSHIP, LAW, AND KNOWLEDGE 7-8 (1994) (explaining the practice of mixed juries in early England).

94. CONSTABLE, supra note 93, at 17 (referencing SiR EDWARd COKE, THE FirST PART OF THE INSTITUTES OF THE LAWS OF ENGLAND \$ 234 (1628)). 
Christians, ${ }^{95}$ city and country dwellers, ${ }^{96}$ and merchants and nonmerchants. ${ }^{97}$ In the United States, the custom of mixed juries was imported from England and used in disputes between settlers and indigenous people, ${ }^{98}$ as well as in other interjurisdictional disputes at least through the beginning of the twentieth century. ${ }^{99}$ Karl Llewellyn's proposal that merchant experts sit as a tribunal to hear commercial disputes relies on a similar idea that specialized communities may possess relevant knowledge or background that should be called upon in rendering just verdicts. 100

The principles underlying mixed juries can still be found today. Indeed, the line of U.S. Supreme Court decisions involving peremptory challenges of jurors, though framed in terms of the individual right to serve on a jury, could be seen as responding in part to the broader idea that jury panels should reflect both racial and gender diversity. ${ }^{101}$ Indeed, research indicates that racially mixed juries tend to deliberate longer, consider more facts, raise more questions, and discuss more racial issues than all-white juries. ${ }^{102}$

In the human rights arena, hybrid domestic/international courts maintain the tradition of the mixed jury. ${ }^{103}$ Such hybrid courts have been employed in transitional justice settings in Kosovo, East Timor, Sierra Leone, and Cambodia. ${ }^{104}$ In these courts, domestic judges-ideally drawn from the multiple political, racial, or ethnic groups involved in the larger geopolitical conflict—sit alongside international

95. See CONSTABLE, supra note 93, at 18-21 (noting that half-Jewish, half-Christian juries heard suits between Jews and non-Jews in England during the twelfth and thirteenth centuries); Ramirez, supra note 93, at 783-84 (arguing that mixed juries originated in part from the king's desire to protect Jewish capital, which was subject to high assessments and escheatment to the Crown, rather than lose it to Christians in an unfair trial).

96. See CONSTABLE, supra note 93 , at 17 (recounting an action involving a country dweller in twelfth-century London that required that at least one of the jurors be of "the county in which the foreigner dwells").

97. See id. at 23-25 (exploring the evolution of "mixed merchant juries" in early England); Ramirez, supra note 93, at 784-86 (recognizing the king's regard for foreign merchants, which prompted the use of mixed juries in order to promote a "perception of fairness" to outsiders and attract their capital and goods).

98. See Katherine A. Hermes, Jurisdiction in the Colonial Northeast: Algonquian, English and French Governance, 43 AM. J. LEGAL HIST. 52, 64-65 (1999) (discussing the implementation of a mixedjury system in colonial Pennsylvania, Rhode Island, and Massachusetts).

99. See Ramirez, supra note 93, at 790 (noting that "[a]t various times between 1674 and 1911, Kentucky, Maryland, Massachusetts, Pennsylvania, New York, Virginia, and South Carolina each provided for mixed juries”).

100. See Zipporah Batshaw Wiseman, The Limits of Vision: Karl Llewellyn and the Merchant Rules, 100 HARV. L. REV. 465, 512-15 (1987) (describing Llewellyn's merchant tribunal proposal).

101. See Batson v. Kentucky, 476 U.S. 79, 89 (1986) (ruling that prosecutors may not challenge jurors solely on the basis of race); J.E.B. v. Alabama, 511 U.S. 127, 130-31 (1994) (extending Batson to peremptory challenges based on gender).

102. Samuel R. Sommers \& Phoebe C. Ellsworth, How Much Do We Really Know About Race and Juries? A Review of Social Science Theory and Research, 78 CHI.-KENT L. REV. 997, 1028 (2003).

103. See, e.g., Laura A. Dickinson, The Promise of Hybrid Courts, 97 AM. J. INT’L L. 295 (2003) (discussing hybrid courts generally and their attempts to provide mixed panels of judges to hear cases).

104. Id. at 295 . 
judges, and domestic and international lawyers also work together to prosecute the cases. ${ }^{105}$

As Stephen Krasner has theorized, the sort of "shared sovereignty"106 reflected in the hybrid court structure can be particularly important when domestic institutions are weak. He argues that shared sovereignty can "gird new political structures with more expertise, better-crafted policies, and guarantees against abuses of power." 107 Following this logic, the Dayton Accords effectively made the Bosnian Constitutional Court a hybrid court, authorizing the president of the European Court of Human Rights to appoint three non-Bosnian judges to the ninemember court. ${ }^{108} \mathrm{~A}$ different kind of hybrid is the Israeli Supreme Court, which has, since its inception, customarily had at least one member who is an expert in Jewish law. 109

We can also see hybrid arrangements outside the judicial context. For example, in the 2000 oil pipeline agreement between Chad and the World Bank, the two parties arranged to share control and governance of the project. ${ }^{110}$ As a condition for its participation, the World Bank insisted on a revenue management plan aimed at ensuring that the proceeds of oil extraction would be used for socioeconomic development. ${ }^{111}$ To that end, the plan contained important limitations on how the expected oil revenue could be invested and spent. ${ }^{112}$ In addition, oversight of the revenue plan was shared. Both the World Bank and the government of Chad had to approve the annual expenditure of revenues, and there was a nine-member oversight committee, seven of whom represented the government while two

105. See id.

106. Stephen D. Krasner, Building Democracy After Conflict: The Case for Shared Sovereignty, 16 J. DEMOCRACY 69, 76 (2005) ("Shared sovereignty involves the creation of institutions for governing specific issue areas within a state-areas over which external and internal actors voluntarily share authority.”).

107. Id. at 70 .

108. See General Framework Agreement for Peace in Bosnia and Herzegovina with Annexes, annex 4, art. VI, 1 1(a), Dec. 14, 1995, 35 I.L.M. 75.

109. See, e.g., Donna E. Arzt, Growing a Constitution: Reconciling Liberty and Community in Israel and the United States, 19 L. \& SOC. INQUIRY 253, 257 (1994).

110. See Emeka Duruigbo, The World Bank, Multinational Oil Corporations, and the Resource Curse in Africa, 26 U. PA. J. INT'L ECON. L. 1, 38-46 (2005), for a useful description of the terms of the project.

111. See id. at 40 .

112. See id. at 41-42 ("In the course of the first ten years of production, that is, between 2004 and 2013, income taxes will constitute sixteen percent of total revenues to Chad and the rest will come from royalties and dividends. The government is given discretion on how to spend the revenues from income taxes subject to the limitation that they be used for general development purposes. The government has less liberty when it comes to royalties and dividends. A Special Revenue Account is created in which they would be deposited. A distribution formula has also been specified. Ten percent of the money will be kept in international financial institutions as a fund for future generations. Eightyfive percent of the remaining ninety percent will be deposited in local commercial banks and is dedicated to the financing of programs in five important sectors namely, education, health and social services, rural development, infrastructure, and environment and water resources. The remaining fifteen percent would be devoted to the development of the oil-producing Doba region."). 
represented civil society. 113 The committee annually published a review of operations, and those operations were subject to external audit. ${ }^{114}$ Finally, the World Bank's International Advisory Group and Inspection Panel retained oversight power over the entire venture. ${ }^{115}$ The result was a hybrid governance structure, neither fully international nor fully domestic.

\section{E. Jurisdictional Redundancies}

Many of the legal conundrums of a hybrid world arise because of jurisdictional redundancy. That is because multiple legal communities frequently seek to assert jurisdiction over the same act or actor. Yet, while this jurisdictional overlap is frequently viewed as a problem because it potentially creates conflicting obligations and uncertainty, we might also view jurisdictional redundancy as a necessary adaptive feature of a multivariate, pluralist legal system. Indeed, jurisdictional redundancy may itself be thought of as a mechanism for managing pluralism because the existence of overlapping jurisdictional claims often leads to a nuanced negotiation-either explicit or implicit-between or among the various communities making those claims.

In focusing on the pluralist opportunities inherent in jurisdictional redundancy, I echo the insights of Robert Cover in his article, The Uses of Jurisdictional Redundancy: Interest, Ideology, and Innovation. ${ }^{116}$ Although his essay was focused particularly on the variety of "official" law pronouncers in the U.S. federal system, Cover identified some of the benefits that accrue from having multiple overlapping jurisdictional assertions, regardless of the context. ${ }^{117}$ Such benefits include a greater possibility for error correction, a more robust field for norm articulation, and a larger space for creative innovation. ${ }^{118}$ And though Cover acknowledged that it might seem perverse "to seek out a messy and indeterminate end to conflicts which may be tied neatly together by a single authoritative verdict," he nevertheless argued that we should "embrace" a system "that permits the tensions and conflicts of the social order" to be played out in the jurisdictional structure of the system. ${ }^{119}$ Thus, Cover's pluralism, though here focused on U.S. federalism, can be said to include the creative possibilities inherent in multiple overlapping jurisdictions asserted by both state and non-state entities in whatever context they arise.

113. Id. at 42 .

114. Id.

115. Id.

116. Robert M. Cover, The Uses of Jurisdictional Redundancy: Interest, Ideology, and Innovation, 22 WM. \& MARY L. REV. 639 (1981).

117. See id. at 642 .

118. See id. at 649 .

119. Id. at 682. 
More recently, Judith Resnik has noted the "multiple ports of entry" that a federalist system creates 120 and has argued that what constitutes the appropriate spheres for "local," "national," and "international" regulation and adjudication changes over time and should not be essentialized.121 Not surprisingly, other commentators have at times advocated what amounts to a federalist approach to national/supranational relations.

\section{F. Migration, Assimilation, and Integration}

Finally, no discussion of legal pluralism as a normative project would be complete without at least surfacing the pressing contemporary issue of the migration of peoples across borders and the stresses caused by such migration. Here, it seems to me that law has a potentially vital role to play as a forum for communication across difference. Indeed, Carol Greenhouse, Barbara Yngvesson, and David Engel, in their study of law and community in three American towns, observed that law is often the terrain of engagement that is used as communities diversify. ${ }^{122}$ In a more homogenous community, where people share history, race, ethnicity, clan ties, social, and religious affiliations, more informal social control mechanisms are available. Transgressors can be shamed and gossiped about, community elders or social leaders can be enlisted to pull people back in line, and so on. But as immigrants enter such communities, those informal dispute resolution mechanisms are less available, and so formal legal processes become more essential. From this perspective, it is perhaps not surprising that law and legal process are so central to U.S. culture; as a society built through wave upon wave of immigration, law was needed as a space to turn enemies into adversaries.

One of the strengths of law as a forum for negotiating difference is that, at least in its ideal state, law can allow for the sort of unassimilated otherness Young envisions. Different narratives and perspectives can be heard, and though power dynamics and entrenched hierarchies still matter, they can, at least sometimes, be overcome. Certainly, law speaks its own language, and people may need to translate their voices into that language in order to be heard. Yet, as discussed previously, the many ports of entry for legal arguments can allow people to gain leverage they might not otherwise have had.

For example, as late as 1994, women in Hong Kong were unable to inherit land. ${ }^{123}$ That year, a group of rural indigenous women joined forces with urban

120. See Judith Resnik, Law's Migration: American Exceptionalism, Silent Dialogues, and Federalism's Multiple Ports of Entry, 115 YALE L.J. 1564 (2006).

121. See Judith Resnik, Afterword: Federalism's Options, 14 YALE L. \& POL'Y REV. 465, 473-74 (1996) ("My point is not only that particular subject matter may go back and forth between state and federal governance but also that the tradition of allocation itself is one constantly being reworked; periodically, events prompt the revisiting of state or federal authority, and the lines move.").

122. See generally CAROL J. GREENHOUSE ET AL., LAW AND COMMUNITY IN THREE AMERICAN TOWNS (1994).

123. Sally Engel Merry \& Rachel E. Stern, The Female Inheritance Movement in Hong Kong: Theorizing the Local/ Global Interface, 46 CURRENT ANTHROPOLOGY 387, 387 (2005). 
women's groups to demand legal change. ${ }^{124}$ As detailed by Sally Engle Merry and Rachel Stern, "The indigenous women slowly shifted from seeing their stories as individual kinship violations to broader examples of discrimination." 125 Ultimately, the women learned to protest these unjust customary laws in the language of international human rights and gender equality. ${ }^{126}$ Having done so, they were successful at getting the inheritance rules overturned. ${ }^{127}$ While we might regret the fact that these women were forced to "translate" their grievances into an internationally recognized language in order to be heard, the success of the movement in accessing political power surely attests to the strength and importance of the international law discourse to their ability to gain a foothold for their claims.

Beyond formal legal process, it may be that the normative ideas underlying legal pluralism can provide responses to the stresses caused by migration more generally. First, of course, pluralism teaches that the whole idea of diversity and otherness need not be seen as a threat to be feared and repelled, but can instead be embraced and cherished. Second, pluralism suggests an alternative response to immigration that is neither full-on assimilation nor exclusion or segregation. By focusing on engagement across difference, communities can honor those differences without dissolving them, while also creating opportunities for integration.

For example, a more pluralist perspective might suggest that France and other countries have gone too far in excluding all symbols of religion in public arenas, such as schools. The goal of creating a secular space for civic engagement may be laudable, but such engagement may actually be more robust if people retain the signifiers of their individual and group identities and engage across difference rather than masquerade in an enforced sameness. On the other hand, encouraging (or even requiring) immigrants to learn the languages of their new communities so that they can participate in a shared social life may be useful. In any event, pluralism as a normative project provides a crucial set of tools for balancing the sometimes conflicting imperatives of maintaining diversity and encouraging integration.

\section{Can Global Legal Pluralism Be Normative and Still Be Pluralist?}

As noted at the outset, global legal pluralism builds upon earlier scholarship focused on legal pluralism in more localized settings. Scholars such as Sally Falk Moore, Leopold Pospisil, Franz and Keebet von Benda Beckmann, Marc Galanter, John Griffiths and Sally Merry turned to legal pluralism as a critique of liberal legality. ${ }^{128}$ And, true to this political agenda, these scholars were skeptical about the hegemonic impact caused by the framing discourse of law itself. They fought against a de-historicized, hierarchical vision of the law that allowed the takeover of the legal

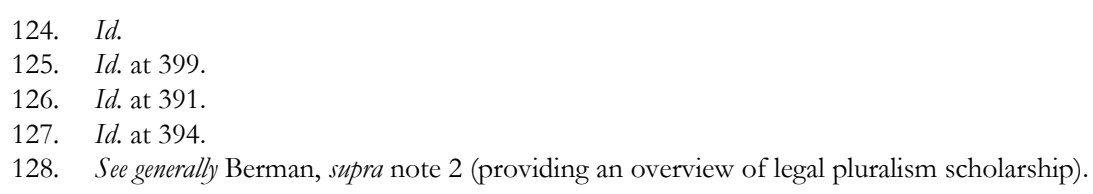


field by state institutions. And they were thus acutely aware that legal pluralism was a radical challenge to the presumed power of official state systems.

Accordingly, one potential concern about global legal pluralism as a normative project is that it will lose this edge of radical critique. In an attempt to be more practically useful, this sort of normative stance might alter legal pluralism such that it becomes less self-suspicious about the hegemony of liberal legal discourse, procedures, and institutions, and instead falls back on such liberal legality in pursuing practical solutions. ${ }^{129}$

This argument is a useful one, and I think it is correct as far as it goes. But that only means that the evolution of global legal pluralism may be on a different trajectory from the original legal pluralists. Indeed, the context and aims of global legal pluralism as a normative project are very different from those of classic legal pluralism. As noted previously, the classic legal pluralists were principally engaged in critique of a dominant view of legality, and they were doing it primarily from the perspective of providing thicker description of cultural practices.

In contrast, global legal pluralism as a normative project is actually trying to advocate a plausible set of institutional arrangements and procedural mechanisms in order to make dominant legal and governmental entities more pluralist in orientation. That is a very different starting point, and it is therefore not surprising that scholars engaged in this normative project do indeed tend to embrace aspects of liberal legality as a given. Thus, it is undoubtedly true that the new generation of global legal pluralists has not severed ties with classic state-based legal theory (and its limits), but it is also true that this new generation is no longer aiming to completely sever such ties in the name of radical critique; scholars are instead trying to introduce more pluralist frameworks into hegemonic structures to make them more accommodating to diversity and hybridity. And that means there will be limitations on the range of hybridity, the language used, and the sorts of arguments entertained. But, these scholars would argue, the result is still better than if no pluralism had been introduced into the framework at all.

Some may not agree. They may say that it's not a truly pluralist vision unless it goes all the way and rejects (or at least challenges) the discourse of law itself. It is fine to make that argument. But I think such critics should at least also acknowledge that such a position makes it difficult to put forward a practical program with a chance of being implemented in a state-based world. In sum, global legal pluralism as a normative project is not an unselfconscious adoption of hegemonic frameworks, but a conscious choice to participate in a discourse about institutional design that otherwise would not be available without adopting certain assumptions and conventions.

And especially at this crucial juncture in history, I think scholars need to spend more time justifying liberal legality and supporting it against the antidemocratic forces

129. See, e.g., Mariano Croce \& Marco Goldoni, A Sense of Self-Suspicion: Global Legal Pluralism and the Claim to Legal Authority, 8 ETHICS \& GLOBAL POL. 1 (2015) (advancing this argument). 
that are circling the globe, rather than focusing on radical critique. There is simply too much at stake. Therefore, even if it dilutes the pluralist vision to justify particular structures of governance, this strikes me as a worthwhile trade-off if the result is a fully voiced justification for a governmental order that at least aims for increased dialogue across difference.

Does this evolution mean that normative legal pluralism is not truly pluralism at all? Certainly the new variants of legal pluralism are less engaged in radical critique and so are willing to countenance liberal legal hegemony even while seeking to open more space for alternative voices within the framework. And, of course, pluralists recognize that whatever governance institutions one creates, they will immediately be challenged, resisted, and subverted in actual practice. But that doesn't mean that those institutional design choices have no impact, and therefore it may be worth thinking about how to make better ones. Thus, it is fair and appropriate to criticize a more normative stance or caution against expecting too much from any particular institutional change. But I think it is unduly doctrinaire and closed-minded to say that such approaches cannot rightly call themselves pluralist or draw on an earlier tradition, even if that tradition were somewhat different. The nature of scholarly threads is that an idea put forth in one context and with one aim can be appropriated and developed in another context for slightly different purposes. And of all people, pluralists should understand that.

Thus, we can perhaps criticize global legal pluralism as a normative project for not being sufficiently counter-hegemonic, but as we do so, we need to first acknowledge that the goals (and institutional roles) of the project are fundamentally different from the original legal pluralist project, which accounts for much of the difference. Second, global legal pluralism as a normative project may often be consistent with liberalism even though it is a structurally different framework; there is no lack of self-consciousness or self-suspicion in that. And, third, we must understand that whether or not a normative stance is somehow inappropriate is not for a purist scholarly gatekeeper to regulate; ideas morph in plural ways, and the vision of global legal pluralism as a normative project may simply be just one of the many plural variants of pluralism, which is as it should be.

\section{CONCLUSION}

In the end, the key question for me is: what sorts of institutional designs, procedural mechanisms, and discursive practices have the best chance of providing effective communication across difference and therefore the best chance of creating a shared social space that might help turn enemies into adversaries? Such approaches need not be perfect and certainly will never be total, but that doesn't mean they can't be helpful and effective. If European institutions, by balancing nation-state sovereignty and supranational authority, have actually contributed to a period of prosperity and peace unrivaled in the entire history of Europe, then those institutions need defending, particularly when they are under attack. If diversity and immigration tend to create long-term societal benefits and lessen extreme 
deprivation of human rights, then someone needs to advocate systems that embrace those values. Of course, no set of legal rules or institutions could ever fully solve the problems of the world, but it seems to me that institutions and practices that seek to manage without eliminating pluralism are better at creating the necessary shared social space for communication across difference, and are therefore better than the available alternatives. And legal pluralists, because of their profound understanding of contestation, diversity, multiplicity, and hybridity, are well positioned to contribute to these and other debates if they choose to do so. 
